\title{
Pengembangan Model Pendidikan Karakter Berbasis Nilai Sosio-Kultural pada Siswa SMA di Minahasa
}

\author{
APELES LEXI LONTO \\ Jurusan PPKn Fakultas IImu Sosial, Universitas Negeri Manado \\ email: Iontolexi@yahoo.co.id
}

\begin{abstract}
Character education become a critical issue in the development of education in Indonesia. This article aims to: (1) identify the problems which faced by teachers; (2) identify the factors determinant cause "deviant behavior" among students; (3) develop an early model of character education based socio-cultural; (4) analyze effectiveness of the educational models. The method used, that is Research Development. This article shows that the teacher in the learning process is still less explores the socio-cultural values of Minahasa. There are internal and eksternal factors causing deviant behavior among the students. Based on these findings, it has developed Model of Character Education Based on Socio-Cultural Values. Development models have produced syllabus, lesson plans and Teaching Materials of PPKn. Expected future conducted similar studies relevant to expand the development of syllabus, lesson plans and Teaching Materials in the school's environment in Minahasa.
\end{abstract}

Keywords: model of character education - socio-cultural values

\begin{abstract}
Abstrak. Pendidikan karakter menjadi isu penting dalam pengembangan pendidikan di Indonesia. Artikel ini bertujuan untuk: (1) mengidentifikasi masalah yang dihadapi oleh guru; (2) mengidentifikasi faktor-faktor penentu yang menyebabkan "perilaku menyimpang" antara siswa; (3) mengembangkan model awal dari pendidikan karakter berbasis sosial budaya; (4) menganalisis efektivitas model pendidikan. Metode yang digunakan, Penelitian Pengembangan. Artikel ini menunjukkan bahwa guru dalam proses pembelajaran masih kurang mengeksplorasi nilai-nilai sosial dan budaya Minahasa. Terdapat faktor internal dan eksternal penyebab terjadinya perilaku menyimpang di antara peserta didik. Berdasarkan temuan ini, telah dikembangkan Model Pendidikan Karakter Berdasarkan Nilai Sosio-kultural. Model-model pembangunan telah menghasilkan silabus, rencana pembelajaran dan pelajaran Bahan Pengajaran PPKn. Diharapkan pada masa mendatang dilakukan penelitian serupa yang relevan untuk memperluas pengembangan silabus, rencana pembelajaran dan Bahan Ajar di lingkungan sekolah di Minahasa.
\end{abstract}

Kata kunci: model pendidikan karakter - nilai sosial budaya

\section{Pendahuluan}

Bangsa Indonesia dewasa ini dihadapkan pada permasalahan yang kompleks dan akut dalam pembentukan karakter sumber daya manusianya. Akar setiap permasalahan yang terjadi di Indonesia, jika ditelusuri, ternyata memiliki keterkaitan erat dengan tabiat atau karakter buruk manusia Indonesia. Keterpurukan kualitas sumber daya manusia di Indonesia dapat dilihat antara lain, pada data Human Development Index selama tiga tahun berturut $(2009,2010,2011)$.
Permasalahan pendidikan yang dihadapi bangsa Indonesia dewasa ini semakin hari tampaknya semakin "berat" antara lain sebagai konsekuensi logis dari lemahnya pendidikan karakter pada masa yang lalu. Pendidikan karakter lebih menonjolkan pengetahuan tentang karakter yang baik sehingga "di atas kertas" setiap peserta didik tampak memiliki karakter yang terpuji, namun demikian dalam kehidupan nyata setiap hari justru tidak selalu demikian. Para siswa mengetahui secara normatif hal-hal yang baik dan benar tetapi mengalami kendala dalam

Received: 27 April 2015, Revision: 12 September 2015, Accepted: 29 Desember 2015

Print ISSN: 0215-8175; Online ISSN: 2303-2499. Copyright@2015. Published by Pusat Penerbitan Universitas (P2U) LPPM Unisba Terakreditasi SK Kemendikbud, No.040/P/2014, berlaku 18-02-2014 s.d 18-02-2019 
melaksanakan apa yang mereka ketahui.

Nilai-nilai sosial budaya yang mengutamakan pembentukan karakter mulia, secara berangsur-angsur mulai dianggap tidak sesuai dengan perkembangan zaman, peserta didik lebih menggemari Budaya Populer (Popular Culture) yang disuguhkan oleh berbagai media yang tersedia di masyarakat. Padahal, setiap daerah memiliki kekayaan budaya yang dapat dikembangkan secara cerdas untuk menjadi dasar pendidikan karakter pada peserta didik yang berada di daerah tersebut.

Seiring dengan meningkatnya kemajuan teknologi di bidang permainan, maka terdapat berbagai jenis permainan yang sangat memikat dan digemari oleh peserta didik. Tanpa disadari, berbagai jenis permainan modern ternyata sarat dengan kemerosotan karakter. Pendidikan karakter anak lebih dominan dibentuk oleh apa yang mereka gemari. Tokoh-tokoh yang licik, suka menyenangkan diri sendiri, suka menang sendiri, menjadi idola karena kemampuannya yang luar biasa; bahkan spiritisme dengan kekuatan ajaib telah menghipnotis peserta didik untuk menghayalkan diri mereka sebagai pribadi yang tangguh, tidak terkalahkan dengan kekuatan sihir yang tidak tertandingi.

Peserta didik yang kepribadiannya telah dibentuk oleh tokoh-tokoh licik, sombong, suka menyenangkan diri, akan sangat sukar menjadi pribadi yang jujur, rendah hati, suka menolong, bahkan mau berlaku adil dan bertanggung jawab. Selanjutnya, mereka kurang mampu melihat keindahan tabiat yang dipantulkan oleh pendidik yang memiliki disiplin yang tinggi dan selalu tegas dalam bertindak. Sebaliknya, sosok pendidik seperti itu akan dianggap sebagai sosok yang buruk dan patut dibenci karena dianggap kaku, ortodoks bahkan dianggap "tidak gaul", suka mengekang dan tidak mengerti selera remaja masa kini.

Sehubungan dengan pentingnya perbaikan dan pembangunan karakter mulia, khususnya bagi peserta didik, Wibowo (2012: 5) menyatakan bahwa "pendidikan karakter hadir sebagai solusi problem moralitas dan karakter". Pendidikan karakter menjadi tanggung jawab bersama antara pemerintah, masyarakat, keluarga dan sekolah.

Permasalahan pendidikan karakter di Minahasa, tidak banyak berbeda dengan permasalahan yang dihadapi bangsa Indonesia pada umumnya. Pendidikan karakter dilaksanakan di setiap sekolah sesuai dengan muatan isi kurikulum yang telah ditetapkan. Padahal, upaya-upaya untuk pengembangan model-model pendidikan karakter sangat dibutuhkan untuk dapat menjadi acuan dalam pelaksanaan pendidikan karakter. Oleh sebab itu, dibutuhkan kajian, baik untuk mengidentifikasi permasalahanpermasalahan pendidikan karakter maupun solusi untuk memecahkan permasalahan tersebut.

Secara nasional, permasalahan yang dihadapi dalam dunia pendidikan tampak semakin hari semakin berat. Berbagai kasus kriminal yang terjadi di antara pelajar menunjukkan adanya masalah karakter yang tidak diperbaiki sehingga memuncak menjadi tindak kriminal. Tawuran yang dilakukan oleh pelajar di berbagai tempat yang diikuti dengan tindak penganiayaan terhadap lawan telah mengarah pada tindakan yang semakin anarkhis dimana hal ini menjadi pemandangan yang memprihatinkan terutama bagi kalangan pendidik dan masyarakat di sekitar tempat kejadian.

Terdapat kecenderungan yang memprihatinkan di kalangan generasi muda peserta didik pada setiap jenjang. Maraknya perkelahian antarsiswa, tumbuhnya kebiasaan merokok dan minum minuman keras, ugalugalan di jalan, berteriak histeris di tengah malam, penggunaan narkoba, terjadinya seks bebas dan aborsi bahkan terjadinya tindak kriminal yang menunjukkan buruknya karakter peserta didik.

Data tentang tindak kriminal yang terjadi di Minahasa di antaranya yang dihimpun berdasarkan data yang ada pada pihak kepolisian Resort Minahasa antara 20102014 menunjukkan bahwa secara berturutturut tampak pada data tindak pidana setiap tahunnya dalam kurun waktu lima tahun tersebut dimana terdapat kecenderungan peningkatan setiap tahunnya. Tindak pidana yang terjadi dalam 2010 terdapat 560 kasus, 2011 terdapat 863 kasus, 2012 terdapat 769 kasus, 2013 terdapat 793 kasus dan 2014 terdapat 817 kasus yang telah dilaporkan oleh masyarakat. Di antara kasus-kasus tersebut yang paling banyak terjadi yaitu kasus penganiayaan (mulai dari kategori penganiayaan biasa dan ringan sampai penganiayaan berat), misalnya data tindak pidana pada 2010, dari 560 kasus terdapat 237 kasus penganiayaan (42,3\%). Di antara para pelaku tindak penganiayaan tersebut adalah para pelajar. Mereka begitu mudah 
terdorong untuk melakukan penganiayaan terhadap orang lain.

Data tersebut mengindikasikan bahwa ada masalah karakter dan pendidikan karakter di antara para pelajar yang terlibat tindak kriminal. Fakta adanya kecenderungan terjadinya peningkatan tindak kriminal merupakan indikasi kegagalan pendidikan khususnya pendidikan karakter di sekolah.

Fakta lainya tentang adanya keluarga terpelajar yang memilih menerapkan jenis pendidikan secara mandiri di dalam rumah khusunya dalam bentuk "Home Schooling" dalam pengembangan pendidikan anak mereka, dengan alasan adanya kekhawatiran bahwa perkembangan karakter anak dapat terkontaminasi dengan perilaku menyimpang jika mereka berada di sekolah formal, hal ini merupakan indikasi lainnya tentang permasalahan pendidikan karakter di sekolah.

Mencermati berbagai kasus yang terjadi di kalangan remaja pelajar yang masih duduk di lembaga pendidikan, tampaknya sebagian besar peserta didik terdorong untuk memasuki pendidikan formal lebih ditujukan untuk mendapatkan ijazah sehingga dapat melamar pekerjaan atau melanjutkan pendidikan yang lebih tinggi setelah lulus.

Kondisi seperti inilah yang menjadikan pendidikan karakter semakin penting untuk terus dikaji sehingga dapat diperbaiki dan ditingkatkan efektivitas dalam pembentukan karakter mulia bagi perserta didik.

Kebangkitan "Generasi Emas Indonesia" yang telah digagas oleh Menteri Pendidikan dan Kebudayaan dalam pidato peringatan Hari Pendidikan Nasional 2 Mei 2012, merupakan sebuah tekad mulia untuk diperjuangkan secara bersama-sama oleh seluruh lapisan masyarakat. Guru sebagai pendidik profesional sudah saatnya menyadari tugas dan tanggung jawab mereka, para guru bukan sekadar pengajar tetapi mereka adalah pendidik yang bertanggung jawab untuk membentuk karakter mulia peserta didiknya.

Upaya untuk mengeksplorasi nilai-nilai budaya yang telah dimiliki oleh masyarakat sebagai dasar untuk pengembangan pendidikan karakter, dan meneliti efektivitas penerapannya sangat penting untuk dilakukan dalam rangka mengeliminasi berbagai perilaku menyimpang akibat kemerosotan karakter mulia di antara peserta didik. Demikian juga peserta didik diharapkan akan lebih tergugah dan lebih mudah untuk memahami dan mempraktikkannya karena nilai-nilai itu telah "hidup" dalam masyarakat di mana mereka berada.

Semboyan yang dimiliki oleh setiap daerah dapat menjadi dasar pendidikan karakter sehingga perlu terus dieksplorasi nilai-nilai luhur yang terkandung di dalamnya selanjutnya pemerintah daerah, masyarakat, keluarga dan pihak sekolah dapat "bergandengan tangan" untuk secara bersama-sama mendukung, memperkuat keterlaksanaan pendidikan karakter yang berbasis pada nilai-nilai kultural yang telah hidup dalam masyarakat.

Oleh sebab itu, artikel ini bertujuan mengidentifikasi permasalahan-permasalahan yang dihadapi guru dalam pendidikan karakter, mengidentifikasi faktor-faktor penyebab terjadinya perilaku menyimpang di antara peserta didik, mengembangkan model awal pendidikan karakter berbasis nilai sosio-kultural, menemukan model pendidikan karakter yang efektif diterapkan dalam pembelajaran PKn

Dengan demikian, hasil tulisan ini diharapkan akan bermanfaat untuk: (1) meminimalisasi terjadinya perilaku menyimpang di antara para siswa di Minahasa; (2) melestarikan nilai-nilai sosial kultural yang mendukung pengembangan pendidikan karakter di Minahasa; (3) menjadi acuan dalam mengatasi hambatan yang dihadapi guru dalam pengembangan pendidikan karakter di Minahasa; (4) menjadi dasar untuk pengembangan model yang dapat diteliti efektivitasnya pada penelitian selanjutnya bahkan dapat menyajikan permasalahanpermasalahan yang relevan untuk dapat diteliti lebih lanjut pada jenjang pendidikan lainnya.

Artikel tentang pendidikan karakter telah banyak dilakukan oleh para peneliti, di antaranya telah dilakukan oleh H.M. Zainuddin yang telah meneliti "Implementasi Model Pembelajaran Group Investigation untuk Pembentukan Karakter Bersahabat" (Mimbar Volume 29 No. 1 (Juni 2013): 69-76. Demikian juga penelitian tentang "Membentuk Karakter Peduli Lingkungan dengan Model Pembelajaran Inkuiri," (Mimbar Volume 30 No. 1 (Juni 2014): 11-17 telah menghasilkan efektivitas dari setiap model yang telah digunakan.

Berbeda dengan tulisan tersebut, dalam artikel ini dilakukan penelitian pengembangan model pendidikan karakter yang berbasis pada nilai sosio-kultural 
dan diharapkan hasilnya dapat diterapkan dalam pembelajaran PKn pada siswa SMA di lingkungan masyarakat Minahasa dan lingkungan etnis lainnya yang memiliki nilai sosio-kultural yang similar.

\begin{abstract}
Menurut Wibowo (2012: 36), pendidikan karakter adalah pendidikan yang menanamkan dan mengembangkan karakter luhur kepada anak didik, sehingga mereka memiliki karakter luhur itu, menerapkan dan mempraktikkan dalam kehidupannya. Pendidikan karakter dapat dipahami sebagai upaya menanamkan kebiasaan tentang hal-hal yang baik sehingga menjadi faham, mampu merasakan dan mau melakukan yang baik dalam segenap kehidupan secara konsisten (Mahpudz, 2010: 10).

Menurut Daniel Goleman, pendidikan karakter merupakan pendidikan nilai yang mencakup sembilan nilai dasar yang saling terkait yaitu: (1) tanggung jawab, (2) rasa hormat, (3) keadilan, (4) keberanian, (5) kejujuran, (6) rasa kebangsaan/kewarganegaraan, (7) disiplin diri, (8) kepedulian, (9) ketekunan (Adisusilo, 2012:79-80).
\end{abstract}

Dalam Undang-Undang Nomor 20 Tahun 2003 tentang Sistem Pendidikan Nasional, pasal 1 ayat (2) diuraikan bahwa pendidikan nasional adalah pendidikan yang berdasarkan Pancasila dan Undang-Undang Dasar Negara Republik Indonesia Tahun 1945 yang berakar pada nilai-nilai agama, dan kebudayaan nasional Indonesia.

Dengan demikian, pendidikan karakter dapat dikembangkan berdasarkan nilai-nilai sosial budaya yang dimiliki dan dihargai oleh suatu masyarakat. Terkait dengan hal ini, Mahpudz (2010:10) menyatakan dalam mengimplementasikan pendidikan karakter tentunya pendidikan karakter dapat berbeda antara satu daerah dengan daerah lainnya bergantung pada kepentingan dan kondisinya masing-masing. Oleh sebab itu dapat dikembangkan model yang sesuai untuk setiap daerah sehingga dapat diterapkan secara efektif di wilayah yang memiliki karakteristik sosial dan budaya yang tidak berbeda.

Model merupakan representasi atau deskripsi sederhana dari kenyataan yang sebenarnya atau konstruk dari kenyataan yang ada (Abas dan Riyanto, 2010:147). Dikaitkan dengan upaya untuk pengembangan model pendidikan karakter yang berbasis nilai-nilai sosio-kultural menunjukkan bahwa terdapat upaya sistematis untuk menanamkan nilainilai kultural yang dimiliki dan dihargai oleh mayarakat.

Model pendidikan karakter berbasis pada nilai-nilai kultural yang dimiliki dan dihargai oleh suatu masyarakat dapat menjadi model yang dapat menggugah emosi dan kebanggaan bagi peserta didik yang hidup di lingkungan masyarakat tersebut. Nilai-nilai ini dapat dieksplorasi untuk diterapkan dalam kehidupan sehari-hari. Model pendidikan karakter berbasis pada nilai-nilai kultural merupakan penguatan terhadap nilai-nilai yang telah dimiliki guna dipraktekkan dalam kehidupan sehari-hari.

Pendidikan nilai merupakan dasar pendidikan karakter (Sauri dan Hufad, 2010:54). Dengan demikian, upaya untuk menanamkan dan mengembangkan nilainilai kultural dari suatu masyarakat dimana peserta didik berada dapat dijadikan sebagai dasar untuk pendidikan karakter. Lebih lanjut Sauri dan Hufad Sauri menjelaskan bahwa:

Pendidikan karakter dapat berbasis pada nilai dalam keluarga dan masyarakat. Keluarga adalah unit sosial terkecil dalam masyarakat. Keluarga dapat berbentuk keluarga inti (nucleus family) yaitu ayah, ibu dan anak, juga dapat berbentuk extended family yaitu kakek/ nenek, mertua, kakak-adik/ipar, dan lain-lain. Di Indonesia extended family paling banyak ditemukan dalam kehidupan masyarakat.

Dalam kehidupan masyarakat, tentu saja tidak akan terlepas dari nilai-nilai budaya yang telah diwariskan dari generasi ke generasi. Namun demikian globalisasi dan berbagai dampaknya ternyata ikut memengaruhi kelestarian nilai-nilai tersebut. Tanpa disadari media massa telah ikut menanamkan nilai-nilai baru yang sering berbenturan dengan nilai-nilai kultural yang telah dimiliki oleh masyarakat. Oleh sebab itu sangat dibutuhkan upaya terencana dan sistematis untuk terus menghidupkan nilainilai kultural yang dapat mencegah peserta didik berprilaku menyimpang.

Pendidikan karakter berbasis nilai (sosial kultural) merupakan langkah yang tepat bagi bangsa Indonesia dalam membangun kehidupan bangsa dimana setiap individu menjadi cerdas, berakhlak mulia, dan mandiri dalam segala dimensi kehidupannya. Pendidikan karakter berbasis nilai merupakan markas penyimpanan kekuatan luar biasa yang memiliki akses ke seluruh aspek kehidupan manusia, memberikan informasi yang berharga tentang pegangan hidup masa depan, serta membantu peserta didik untuk mempersiapkan kebutuhan esensialnya dalam menghadapi perubahan (Sauri dan Hufad, 2010:54).

Dengan demikian, pendidikan karakter berbasis pada nilai-nilai sosio-kultural dapat dijadikan sebagai salah satu model 
pendidikan karakter bagi masyarakat yang ada di Minahasa, Sulawesi Utara. Meskipun masyarakat di Minahasa terdiri atas beberapa kelompok etnis dan sub-etnis, tetapi pada dasarnya memiliki kesamaan nilai-nilai dasar yang tergambar secara jelas dalam setiap semboyan daerah kabupaten/kotanya masing-masing.

Pendidikan karakter berbasis nilai-nilai sosial kultural dapat dikembangkan dari semboyan hidup dari tiap daerah di Sulwesi Utara, misalnya semboyan daerah kabupaten Sangihe: Somahe Kai Kehage yang bermakna pantang menyerah dalam menghadapi apa pun, tidak banyak berbeda dengan semboyan Gambaru atau berjuang mati-matian sampai titik darah penghabisan yang begitu dipegang kuat oleh orang Jepang. Sudah saatnya untuk menggali atau mengeksplorasi nilainilai sosial budaya yang ada di setiap daerah untuk diberikan makna yang lebih dalam guna pengembangan karakter peserta didik.

Eksplorasi dan implementasi nilainilai budaya yang telah dimiliki oleh suatu masyarakat dapat lebih efektif dikembangkan dalam pendidikan karakter, hal ini sejalan juga dengan semangat desentralisasi pendidikan yang menekankan pada tanggung jawab bersama antara pemerintah daerah, masyarakat, keluarga dan sekolah. Sekolah dapat membangun budaya sekolah berdasarkan nilai-nilai yang telah dimiliki oleh masyarakat. Masyarakat dapat memberikan dukungan yang kuat untuk terus melaksanakannya disertai kebijakan pemerintah daerah untuk mengukuhkan dan melegitimasinya.

Sehubungan dengan pentingnya pengembangan model pendidikan karakter yang efektif untuk diterapkan dalam pembelajaran $\mathrm{PKn}$ maka dalam penelitian ini dapat digunakan pendekatan dan metode penelitian yang sesuai untuk pencapaian tujuan yang telah ditetapkan.

Artikel ini dirancang berdasarkan pendekatan penelitian kualitatif dengan metode penelitian pengembangan guna pengembangan model pendidikan karakter pada Sekolah Menengah Atas (SMA yang berada di lingkungan sosio-kultural Minahasa) yang difokuskan untuk mengidentifikasi permasalahan yang dihadapi guru dalam pendidikan karakter; mengidentifikasi faktor-faktor determinan penyebab perilaku menyimpang di kalangan siswa; dan berdasarkan hasil penelitian tahap pertama tersebut dapat dilanjutkan dengan penelitian pengembangan guna menemukan model pendidikan karakter yang efektif untuk diterapkan dalam proses pembelajaran PKn pada siswa kelas 1 SMA.

Dengan demikian dalam Metode Penelitian Pengembangan (Research and Development) ini telah diterapkan langkahlangkah pengembangan model yang diadaptasi dari desain pengembangan model yang dikembangkan oleh Walter Dick \& Lou Carey dalam Gall \& Borg (2003:571).

Adapun langkah-langkah pengembangan model yang digunakan dalam penelitian ini, adalah sebagai berikut: (1) Melakukan studi pendahuluan untuk mengidentifikasi masalah, menganalisis hambatan yang dihadapi guru guna pengembangan model awal. Dilaksanakan pada tahun 2013; (2) Merancang dan mengembangkan model berdasarkan kajian teoretik dan data empiris hasil studi pendahuluan. (3) Penerapan model dalam pendidikan karakter di tujuh SMA yang ada, yaitu: (a) SMA Negeri 1 Tondano, (b) SMA Negeri 1 Tomohon, (c) SMA Negeri 1 Amurang, (d) SMA Negeri 1 Manado, (e) SMA Negeri 1 Tombatu, (f) SMA Negeri 1 Airmadidi, dan (g) SMA Negeri 1 Bitung. Dilaksanakan pada tahun 2014; (4) Analisis dan evaluasi penerapan model secara bertahap mulai dari Antecedents (kondisi awal lingkungan penerapan model), Transactions (Proses penerapan model) and Outcomes (Hasil dan dampak penerapan model).

Berdasarkan hasil evaluasi tersebut, dilakukan revisi, demikian seterusnya sampai ditemukan model yang layak (MODEL AKHIR) untuk diterapkan dan efektif dalam pendidikan karakter.

Secara keseluruhan metode penelitian pengembangan model pendidikan karakter berbasis nilai sosio-kultural di Minahasa dapat divisualisasikan pada Gambar 1 berikut ini:

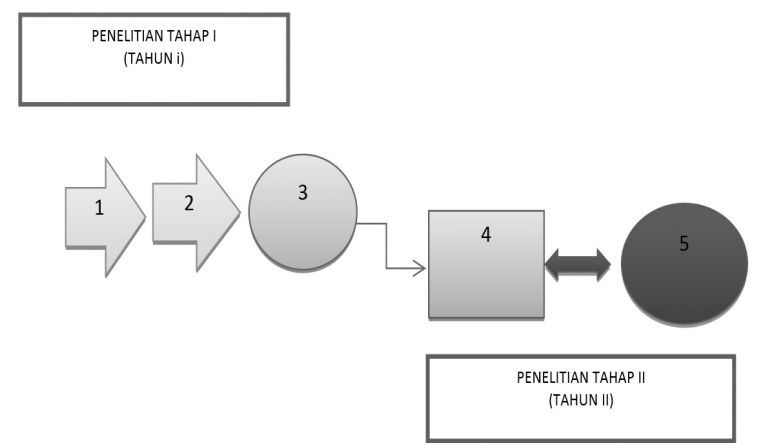

Gambar 1

Tahap Pengembangan 
Teknik pengumpulan data: observasi, wawancara, dan dokumentasi. Teknik analisis data yang akan digunakan dalam penelitian ini adalah teknik analisis data yang dikembangkan oleh A. Michael Huberman \& Matthew B. Miles (1994: 429) yaitu: (1) data reduction; (b) data display; (c) conclusions: drawing and verifying.

\section{Permasalahan yang Dihadapi Guru dalam Pendidikan Karakter}

Permasalahan yang dihadapi guru dalam pendidikan karakter yaitu: Pertama, maraknya media sosial yang menyajikan budaya popular yang demikian mempengaruhi pola pikir, sikap dan tindakan sebagian besar siswa. Kedua, para guru lebih berorientasi dan terikat pada muatan atau isi kurikulum demi mengejar pencapaian target yang telah ditetapkan dalam kurikulum. Ketiga, para guru belum banyak melakukan eksplorasi nilai-nilai sosial budaya lokal bahkan ada yang mulai mengabaikannya karena sudah mulai terkikis dari kehidupan masyarakat yang semakin modern. Keempat, kurangnya keteladanan dari guru sendiri dalam mendemonstrasikan nilai-nilai sosial budaya setempat. Kelima, sekolah belum mengintegrasikan nilai-nilai sosio-kultural sebagai bagian dari nilai budaya organisasi sekolah.

\section{Faktor Penyebab Terjadinya Perilaku Menyimpang}

Terdapat faktor internal dan eksternal penyebab terjadinya perilaku menyimpang di antara peserta didik SMA di Minahasa. Secara internal kurangnya pengendalian diri akibat melemahnya pemikiran untuk memahami dan menyikapi konsekwensi logis perilaku menyimpang. Data hasil wawancara terhadap peserta didik menunjukkan bahwa ketika mereka melakukan hal-hal yang menyimpang seperti bagate atau minum cap tikus (minum minuman keras produksi lokal), ba ehabond (menghirup ehabond - sejenis lem yang memiliki zat adiktif dan aroma yang keras), ba dola en ba pajak (menghadang dan memaksa meminta uang), bakalae (berkelahi), ba tona bebas (pacaran dan melakukan seks bebas), ba ebong (pacaran dengan teman sejenis); pada saat itu mereka lupa bahkan tidak peduli lagi dengan akibat-akibat perbuatan menyimpang tersebut. Mereka menyatakan vor torang yang penting enjoy yang laenglaeng urusan kablakang (bagi kami yang penting menikmati dulu yang lain-lain urusan belakangan). Sedangkan secara eksternal dipengaruhi oleh: (1) media sosial, (2) peran orang tua; (3) lingkungan kehidupan masyarakat terutama teman sebaya (4) peran dan kebijakan pemerintah.

\section{Pengembangan Model Pendidikan Karakter Berbasis Nilai-Nilai So- sio-Kultural}

Berdasarkan dua temuan tersebut selanjutnya dikembangkan model awal Pendidikan Karakter Berbasis Nilai-Nilai SosioKultural pada siswa kelas 1 SMA di Kabupaten Minahasa, dengan cara mengintegrasikan nilai sesuai dengan isi kurikulum, selanjutnya menyusun Silabus dan RPP serta menyiapkan Materi Pelajaran. Langkah berikutnya yaitu menerapkannya dalam proses pembelajaran pada tujuh SMA yang telah ditentukan.

Hasil analisis dan evaluasi menunjukkan bahwa faktor antecedents yang telah diidentifikasi pada studi pendahuluan ternyata sangat berpengaruh terhadap faktor transactions dalam proses pembelajaran dan outcomes pada hasil yang dicapai. Setelah dilakukan uji-coba sebanyak tiga kali putaran, ternyata dibutuhkan intervensi tindakan untuk perbaikan faktor antacedents. Oleh sebab itu dilakukan intervensi tindakan untuk memperkuat faktor antacedents yaitu dengan mempersiapkan guru secara maksimal untuk menerapkan model. Persiapan ini dilakukan selama dua bulan untuk memberikan pelatihan bagi para guru.

Hasil akhir menunjukkan bahwa ternyata model ini dapat diterapkan dengan memenuhi sedikitnya empat prasyarat utama yaitu: Pertama, guru PKn perlu menguasai nilai-nilai sosio-kultural masyarakat Minahasa yang dapat dikategorikan dalam sembilan nilai dasar yang universal dalam pendidikan karakter. Kedua, tersedia rumusan silabus dan RPP yang berisi langkah-langkah penerapan Model Pendidikan Karakter Berbasis Nilai Sosio-Kultural. Ketiga, tersedia bahan Ajar yang berisi nilai-nilai sosio-kultural masyarakat Minahasa. Keempat, komitmen guru untuk menerapkannya.

Komitmen guru untuk menerapkan model ini selanjutnya akan mendorong guru untuk terus mengeksplorasi nilai-nilai sosio-kultural yang relevan dengan setiap cakupan materi yang telah digariskan dalam kurikulum.

Kenyataan bahwa tidak ada masyarakat yang berkembang tanpa adanya landasan nilai-nilai sosio-kultural menunjukkan bahwa ternyata nilai-nilai sosio kultural telah melekat dalam kehidupan masyarakat. Disinilah 
kalangan pendidik dan ilmuwan di bidang pendidikan sosial budaya dituntut untuk dapat mengekspolarasinya secara terus menerus guna mengantisipasi perkembangan dan tuntutan kehidupan peserta didik yang demikian dinamisnya.

Pengembangan aspek sosio-kultural dapat dianggap juga sebagai pendekatan yang berpandangan bahwa sosialisasi bahkan penanaman nilai sosio-kultural akan berhasil bila didukung oleh lingkungan sosial budaya di sekitarnya (Lonto \& Pangalila, 2013: 111). Dalam konteks lingkungan sosial budaya di sekitar siswa, maka lingkungan rumah, sekolah dan masyarakat memiliki peran penting untuk mendukung upaya sosialisasi dan penanaman bahkan pelestarian nilai-nilai sosio-kultural tersebut guna pembentukan karakter mulia.

Sekolah perlu membangun budaya organisasi sekolah yang berbasis pada kearifan lokal yang telah dimiliki oleh masyarakat di sekitar lingkungan sekolah. Sekolah dapat mengembangkan budaya organisasinya dengan memadukan nilai-nilai sosio-kultural dan pendekatan-pendekatan lainnya yang relevan. Dalam lingkungan keluarga dan masyarakat, menurut Lonto dan Pangalila (2013:112) dapat dikembangkan pola pewarisan nilai yang dapat diadaptasi dari Larson \& Smalley seperti yang telah dikutip oleh Mustadi (2012) bahwa nilai-nilai sosio-kultural sebagai "sebuah blue print yang menuntun perilaku manusia dalam sebuah masyarakat dan ditetaskan dalam keluarga".

Nilai-nilai sosio-kultural dapat dijadikan norma yang mengatur tingkah laku seseorang dalam kelompok, membuat seseorang sensitif terhadap status, dan membantunya mengetahui apa yang diharapkan orang lain terhadap dirinya dan apa yang akan terjadi jika tidak memenuhi harapan-harapan mereka. Sosio-kultural membantu seseorang untuk mengetahui seberapa jauh dirinya dapat berperan sebagai individu dan apa tanggung jawab dirinya terhadap kelompok (Lonto \& Pangalila, 2013: 112).

Dengan demikian, pengembangan model pendidikan karakter yang berbasis pada nilai-nilai sosio-kultural masyarakat Minahasa merupakan pengembangan sekaligus penguatan terhadap fungsi nilai sosio-kultural yang dapat dijadikan norma yang dapat mengatur perilaku siswa baik di dalam lingkungan sekolah maupun keluarga dan masyarakat.

\section{Efektivitas Penerapan Model Pen- didikan Karakter Berbasis Nilai So- sio-Kultural}

Artikel ini menunjukkan bahwa Model Pendidikan Karakter Berbasis Nilai-Nilai Sosio-Kultural Minahasa secara efektif dapat diterapkan pada peserta didik yang bermukim di wilayah yang dihuni oleh mayoritas masyarakat Minahasa yang tersebar di Kabupaten Minahasa, Minahasa Utara, Minahasa Selatan, Minahasa Tenggara, Kota Bitung dan Kota Tomohon. Penerapan model pendidikan karakter berbasis nilai-nilai sosiokultural Minahasa ternyata bersifat fleksibel untuk diintegrasikan dalam kurikulum Pendidikan Kewarganegaraan.

Dalam Kurikulum 2006 dan 2013 pada mata pelajaran PKn untuk kelas 1 terdapat sebaran kompetensi inti, yaitu menghayati nilai-nilai Pancasila dalam kehidupan bermasyarakat, berbangsa dan bernegara, kompetensi inti ini dapat dijabarkan dalam sejumlah kompetensi dasar yang relevan dengan nilai-nilai sosial budaya di Minahasa. Salah satu contoh yaitu nilai persatuan secara langsung dapat dihubungkan dengan nama "Minahasa" yang berarti disatukan. Persatuan merupakan sebuah wujud dari sebuah proses untuk menjadi satu dalam sebuah aktivitas penyatuan. Disatukan merupakan sebuah kesepakatan masyarakat untuk menjadi satu.

Dalam ruang lingkup pendidikan karakter sebagai pendidikan nilai yang mencakup sembilan nilai dasar yang saling terkait satu sama lainnya sebagaimana yang telah dijabarkan oleh Daniel Goleman (Adisusilo, 2012:79-80), yaitu: (1) tanggung jawab, (2) rasa hormat, (3) keadilan, (4) keberanian, (5) kejujuran, (6) rasa kebangsaan/kewarganegaraan, (7) disiplin diri, (8) kepedulian, (9) ketekunan, maka eksplorasi dan aplikasi nilai sosio-kultural yang telah hidup di lingkungan sosiokultural masyarakat Minahasa, ternyata dapat membangkitkan rasa bangga bagi masyarakat setempat dan inilah modal sosial yang dapat mendukung penerapannya dalam pendidikan karakter di lingkungan sosial budaya setempat.

Terdapat ikatan emosional yang kuat dalam mengenali dan mengembangkan kekayaan budaya leluhur Minahasa di kalangan peserta didik yang secara sosio-kultural masih terikat dengan simbol-simbol budaya yang menjadi kebanggaan masyarakatnya. Pemberian nama Minahasa yang berarti "disatukan" ternyata mengandung makna yang lebih dalam dan lebih luas lagi, tidak hanya sekedar disatukan tetapi ada nilai-nilai dasar yang melatarbelakanginya sehingga 
perlu terus dieksplorasi dan diaplikasikan sesuai dengan fungsi dan konteksnya.

Oleh sebab itu, perlu terus dikembangkan apa makna disatukan, siapa saja yang harus bersatu, kapan dan dimana harus bersatu, bagaimana proses untuk bersatu, mengapa dan untuk apa harus bersatu. Di sinilah dibutuhkan upaya kreatif guru untuk memberikan arah yang positif sehingga persatuan tidak diselewengkan maknanya menjadi sebuah persatuan dari suatu "komplotan" atau "geng" yang ekslusif bahkan merasa diri lebih tinggi derajatnya dari orang lain (Chauvinisme).

Dengan demikian dalam sembilan cakupan nilai pendidikan karakter ternyata, dapat dikaitkan dengan nilai-nilai sosiokultural yang telah ada dan dihargai oleh masyarakat Minahasa. Masyarakat Minahasa yang disatukan tentu saja memiliki tanggung jawab untuk bersatu dan mempertahankan persatuan tersebut, memiliki rasa hormat terhadap satu sama lain, sehingga mereka dapat bersatu dan terus bersatu, mereka memiliki prinsip keadilan dalam tatanan persatuan masyarakatnya, memiliki keberanian, menghargai kejujuran, menjunjung tinggi rasa kebangsaan/kewarganegaraan, mampu mengendalikan diri, peduli terhadap satu sama lain, dan memliki ketekunan hidup. Sembilan nilai tersebut tergambar jelas dalam perbendaharaan bahasa dari setiap sub-etnis Minahasa.

Bagi sub-etnis Tountemboan dikenal istilah Tinokean in Tawoiean yang berarti Tanggung jawab; Awean Kasiri'an Ase Tou yang berarti Rasa Hormat; Ra'ica Marapit/ Ra'ica Wana em Perapitan yang berarti Adil atau Keadilan; Awe'an Kebranian yang berarti Keberanian; Ra'ica Matowo yang berarti Kejujuran, Tou Minahasa Indonesia yang berarti Orang Minahasa berkebangsaan/ kewarganegaraan Indonesia; Mekawali/ Mekawali in Owak ang Kalooran yang berarti Pengendalian Diri; Pandung/Mengapandung yang berarti Kepedulian; Le'tek/Kale'tekan yang berarti Ketekunan.

Kesembilan nilai sosio-kultural tersebut dapat dielaborasi untuk didemonstrasikan dalam proses pembelajaran di kelas. Pencapaian tujuan pendidikan yang telah dijabarkan dalam kurikulum dapat dilakukan dengan memadukan muatan isi kurikulum dengan nilai-nilai sosio-kultural yang relevan.

Dengan demikian, Model Pendidikan Karakter Berbasis Nilai Sosio-Kultural ternyata secara efektif dapat diterapkan dalam pendidikan karakter siswa pada mata pelajaran PKn. Efektivitas penerapannya tampak pada dua hal yaitu: pertama, dalam suplemen isi/ muatan kurikulum, pengembangan silabus dan RPP bahkan bahan ajar. Kedua, dalam proses pembelajaran. fleksibilitas penerapan nilai-nilai sosio-kultural dapat dimasukkan dalam muatan atau isi kurikulum yang relevan.

Selanjutnya, dijabarkan dalam pengembangan silabus, RPP dan bahan ajar. Dalam proses pembelajaran siswa tampak antusias untuk belajar bahkan di antara para siswa yang telah memiliki pengetahuan awal mereka sangat antusias dan berpartisipasi aktif dalam proses pembelajaran. Para siswa yang telah mengetahui nilai-nilai sosio-kultural di lingkungan masyarakat Minahasa bahkan dapat menyebutkan nilainilai tersebut disertai dengan contoh-contoh kongkrit yang mereka ketahui.

Namun demikian, kendala yang dihadapi sekarang ini, yaitu maraknya informasi media sosial yang berisi budaya popular menyajikan kehidupan modern yang sarat dengan kehidupan bebas, pornografi, kekerasan, dan hedonisme; melemahnya pengawasan orang tua dan masyarakat, menjadi tantangan berat bagi guru PKn. Selain itu juga kendala lainnya yang datang dari guru itu sendiri, yaitu kurangnya keteladanan dalam hal satunya kata dan tindakan, dimana setiap saat dapat menjadi contoh sekaligus cermin bagi peserta didik. Oleh sebab itu, komitmen guru untuk mengeksplorasi dan menerapkan nilai-nilai sosio-kultural yang dihargai di lingkungan masyarakatnya menjadi faktor penting yang ikut menentukan hasil selanjutnya sehingga guru menjadi teladan dalam penerapan nyata dalam kehidupan sehari-hari.

\section{Simpulan dan Saran}

Permasalahan-permasalahan yang dihadapi guru dalam pendidikan karakter, yaitu: Pertama, maraknya media sosial yang menyajikan budaya popular. Kedua, para guru lebih berorientasi dan terikat pada muatan atau isi kurikulum. Ketiga, para guru belum banyak melakukan eksplorasi nilai-nilai sosial budaya lokal Minahasa. Keempat, kurangnya keteladanan dari guru. Kelima, sekolah belum mengintegrasikan nilai-nilai sosio-kultural

Terdapat faktor internal dan eksternal penyebab terjadinya perilaku menyimpang di antara peserta didik SMA di Minahasa. Secara internal, kurangnya pengendalian diri akibat melemahnya pemikiran untuk memahami dan menyikapi konsekwensi logis perilaku menyimpang seperti bagate atau minum cap tikus (minum minuman keras produksi lokal), ba ehabond (menghirup ehabond - sejenis lem yang memiliki aroma yang keras), ba dola en ba pajak (menghadang dan memaksa 
meminta uang), bakalae (berkelahi), ba tona bebas (pacaran dan melakukan seks bebas), ba ebong (pacaran dengan teman sejenis); Sedangkan secara eksternal dipengaruhi oleh (1) media sosial, (2) peran orang tua; (3) lingkungan kehidupan masyarakat terutama teman sebaya (4) peran dan kebijakan pemerintah.

Model Pendidikan Karakter Berbasis Nilai-Nilai Sosio-Kultural, yaitu Model Pendidikan karakter berdasarkan nilai-nilai dasar sosio-kultural yang dimiliki masyarakat Minahasa yaitu: (1) Tinokean in Tawoiean yang berarti Tanggung jawab; (2) Awean Kasiri'an Ase Tou yang berarti Rasa Hormat; (3) Ra'ica Marapit/Ra'ica Wana em Perapitan yang berarti Adil atau Keadilan; (4) Awe'an Kebranian yang berarti Keberanian; (5) Ra'ica Matowo yang berarti Kejujuran, (6) Tou Minahasa Indonesia yang berarti Orang Minahasa berkebangsaan/kewarganegaraan Indonesia; (7) Mekawali/Mekawali in Owak ang Kalooran yang berarti Pengendalian Diri; (8) Pandung/Mengapandung yang berarti Kepedulian; (9) Le'tek/Kale'tekan yang berarti Ketekunan.

Artikel ini merekomendasikan penelitian lanjutan untuk pengembangan model ini bagi siswa kelas 2 dan 3 SMA, bahkan pada jenjang pendidikan lainnya. Kiranya pihak perguruan tinggi yang mengemban tanggung jawab di bidang pendidikan, penelitian dan pengabdian kepada masyarakat senantiasa dapat berpartisipasi dalam pengembangan nilai-nilai sosial budaya yang menjadi kearifan lokal untuk penguatan pendidikan karakter bagi peserta didik.

\section{Daftar Pustaka}

Abas, T dan Riyanto, A. A. (2010). Model Pembelajaran Kewirausahaan Bidang Busana Berbasis Gaya Belajar Mahasiswa, dalam Potret Profesionalisme Guru dalam Membangun Karakter Bangsa: Pengalaman Indonesia dan Malaysia. Konferensi Internasional Pendidikan
Guru ke-4 (UPI-UPSI), Pendidikan Guru Untuk Membangun Karakter dan Budaya Bangsa, 8 - 10 Nopember 2010, Bandung: Universitas Pendidikan Indonesia.

Adisusilo, S. (2012). Pembelajaran NilaiKarakter: Konstruktivisme dan VCT sebagai Inovasi Pendekatan Pembelajaran Afektif. Jakarta: Rajagrafindo Persada.

Lonto dan Pangalila. (2013). Etika Kewarganegaraan. Yogyakarta: Ombak.

Mahpudz, A. (2010). Pendidikan Karakter dalam Membangun Sumber Daya Manusia yang Berakhlak Mulia: Tantangan dan Peluang Implementasi Di Persekolahan dalam Prayoga Bestari \& Syaifullah Syam, Pendidikan Pancasila dan Kewarganegaraan dalam Membangun Karakter Bangsa (Nation and Character Building): Refleksi, Komitmen dan Prospek, Bandung: Laboratorium Pendidikan Kewarganegaraan FPIPS UPI.

Miles, M. B \& Huberman, A. M., (1994). Data Management and Analysis Methods in Norman K. Denzin \& Yvonna S. Lincoln (editors), Hand book of Qualitative Research, Thousand Oak, California: Sage Publications, Inc.

Mustadi, A. (2010). Pendidikan Karakter Berwawasan Sosiokultural (Sociocultural Based Education). [Online]. Available: uny.ac.id. (Diakses:12 Februari 2015).

Sauri, S \& Hufad, A. (2010). Pendidikan Karakter Berbasis Nilai: Antara Makna, Urgensi dan Praksis, dalam Potret Profesionalisme Guru dalam Membangun Karakter Bangsa: Pengalaman Indonesia dan Malaysia. Konferensi Internasional Pendidikan Guru ke-4 (UPI-UPSI), Pendidikan Guru Untuk Membangun Karakter dan Budaya Bangsa, 8 - 10 Nopember 2010. Bandung: Universitas Pendidikan Indonesia.

Undang-Undang No. 20 Tahun 2003 tengan Sistem Pendidikan Nasional.

Wibowo, A. (2012). Pendidikan Karakter: Strategi Membangun Karakter Bangsa Berperadaban. Yogyakarta.

Zainuddin, H. M. Mimbar, Vol. XXIX, No. 1 (Juni, 2013): 69-76. "Terakreditasi" SK Dikti. No. 64a/DIKTI/Kep/2010.

Zainuddin, H. M. dkk. Mimbar, Vol. XXX, No. 1 (Juni, 2014):11-17. "Terakreditasi" SK Dikti No. 040/P/2014. 